\title{
Constraints for nutritional grouping in Wisconsin and Michigan dairy farms
}

\author{
F. E. Contreras-Govea, ${ }^{*}$ V. E. Cabrera, ${ }^{* 1}$ L. E. Armentano, ${ }^{*}$ R. D. Shaver, ${ }^{*}$ P. M. Crump,† D. K. Beede,‡ \\ and M. J. VandeHaar‡ \\ *Department of Dairy Science, and \\ †Department of Computing and Biometry, University of Wisconsin, Madison 53706 \\ ‡Department of Animal Science, Michigan State University, East Lansing 48824
}

\section{ABSTRACT}

A survey was conducted in Wisconsin (WI) and Michigan (MI) to quantify the proportion of farms that use a single diet for all lactating cows and to better understand the reasons for current grouping strategies and the limitations to grouping for better nutritional management. A questionnaire was mailed to all WI dairy farmers with $\geq 200$ lactating cows (971 farms) and to a random sample of grade-A MI dairy farmers (800 farms) of varying herd sizes. The survey return rate was 20\% in WI (196 farms) and 26\% in MI (211 farms; 59 of them had $\geq 200$ lactating cows). Feeding 2 or more different diets to lactating cows was predominant: $63 \%$ in WI (124 farms, all $\geq 200$ lactating cows), $76 \%$ in MI farms with $\geq 200$ lactating cows ( 45 farms), and $28 \%$ in MI farms with $<200$ lactating cows (43 farms). Farmers feeding more than 1 diet used 1 or more of the following criteria for grouping lactating cows: stage of lactation, milk production, or body condition score. Overall for both states, $52 \%$ of the farms (211 from 407 farms) feeding more than 1 diet grouped cows according to their nutritional needs. However, a notable population of farms fed the same diet to all lactating cows: $37 \%$ in WI (72 farms), $24 \%$ in MI (14 farms) for herds of $\geq 200$ lactating cows, and $72 \%$ in MI for herds of $<200$ lactating cows (109 MI farms). "Desire to keep it simple" and "milk drops when cows are moved to a different group" were identified as main constraints to having more groups within a farm for nutritional purposes. Farm facilities and labor were also limiting factors to grouping in farms with herd sizes of $<200$ lactating cows.

Key words: feed efficiency, precision feeding, diet management, survey

Received May 15, 2014.

Accepted October 27, 2014

${ }^{1}$ Corresponding author: vcabrera@wisc.edu

\section{INTRODUCTION}

A major challenge in feeding high-producing dairy cows has been to find the right nutritional balance (fiber, NFC, protein, and fat) to promote rumen health and maximize feed energy intake and nutrient flow to the mammary gland for milk synthesis (VandeHaar et al., 2012). Also, a major limitation to increase feed efficiency in many dairy farms is the unwillingness of farmers to group cows according to their nutritional needs, because feeding a single diet across lactation cannot maximize both production and efficiency simultaneously (VandeHaar et al., 2012). McGilliard et al. (1983) developed a method for grouping dairy cows based on protein and energy requirements (cluster). That method was compared against grouping by daily test milk, FCM, or dairy merit. The cluster procedure was the most effective for grouping cows and was more homogeneous to meet their nutrient requirements (McGilliard et al., 1983). Schucker et al. (1988) performed a validation study and follow-up studies by Williams and Oltenacu (1992) and St-Pierre and Thraen (1999) corroborated that cows grouped by their energy and protein nutrient requirements were more homogeneous than cows grouped by milk production.

Managing multiple-diet groups across lactation has the potential to improve productivity, efficiency, and feed cost savings to dairy producers (Williams and Oltenacu, 1992; Allen, 2009; Zwald and Shaver, 2012). Based on the cluster method (McGilliard et al., 1983), Cabrera et al. (2012) developed and tested an online tool, "Grouping strategies for feeding lactating dairy cows" (http://dairymgt.uwex.edu/tools.php), to group cows based on nutrient requirements and income over feed cost. The analysis was conducted using data for cow identification, parity, DIM, milk yield, and milk fat content from $30 \mathrm{Wisconsin}$ commercial farms. The analysis consistently demonstrated that income over feed cost in all farms was greater for the strategy of using 3 feeding groups per farm than a no grouping strategy (Cabrera et al., 2012).

Previous research supports the practice of grouping animals and adjusting diets according to their energy 
requirements to maximize feed efficiency and profitability in dairy farms (Allen, 2009; Maltz, et al., 2013); tools already exist to facilitate this task. However, the proportion of dairy farms in the upper Midwest grouping lactating cows according to nutritional requirements or conducting any management to enhance feed efficiency of lactating cows is unknown. Furthermore, the reasons for current grouping practices and constraints to implementing greater grouping are poorly understood. Therefore, the objective of the current survey study was to quantify the proportion of farms that uses a single diet for all lactating cows in commercial dairy farms in Wisconsin (WI) and Michigan (MI) and to better understand the reasons for current grouping strategies and the limitations (perceived or real) to grouping for better nutritional management.

\section{MATERIALS AND METHODS}

A survey instrument was developed, reviewed, and approved by the University of Wisconsin-Madison Education Research and Social and Behavioral Science Institutional Review Board. The survey was mailed to 971 farmers in WI and 800 farmers in MI. All WI farmers with $\geq 200$ milking cows and a random sample of MI grade-A dairy farmers were invited to participate. The survey package contained (1) a consent form explaining that the survey was reviewed and authorized by the Education Research and Social Behavioral Science Internal Review Board at the University of WisconsinMadison and researchers' contact information; (2) a letter briefly describing the goals and objectives of the project, indicating that this project was supported by the Agriculture and Food Research Initiative Competitive Grant no. 2010-85122-20612, with a list of participating universities and faculties, and a survey code number so that the producer could complete the questionnaire online if desired; (3) a 2-page questionnaire; and (4) a preaddressed, stamped return envelope. All potential respondents were informed that the questionnaire was anonymous unless they chose to divulge their identity at the end of the questionnaire. The questionnaire had 2 sections: (1) basic dairy farm information and (2) feeding and diets for lactating cows. Section A had 8 questions about dairy cattle numbers, rolling herd average (RHA) and individual cow milk production, primary manager of the farm, who performs the role of nutritionist, pasture-based farm (or not), certified organic (or not), housing facilities, and reasons for current physical grouping of lactating cows. In the questions of reasons for current physical grouping of lactating cows, Likert scale (Bowling, 2009) ranks from 1 to 5 were provided to assess the level of farmer agreement to formulated statements. A rank of 3.0 meant the farmer neither agreed nor disagreed with the statement (neutral), rankings closer to 1.0 meant the farmer disagreed or strongly disagreed with the statement, and a rank closer to 5.0 meant that the farmer agreed or strongly agreed with the statement. Section B was divided into 4 questions about (1) feeding different diets to different groups of lactating cows; (2) reasons for grouping lactating cows for feeding purposes; (3) feeding systems for lactating cows; and (4) constraints to feeding groups of lactating cows. Reasons for grouping lactating cows for feeding purposes and constraints to feeding groups of lactating cows (second and fourth questions) also had Likert scale responses ranked from 1 , strongly disagree, to 5 , strongly agree.

The data were analyzed using the nonparametric Wilcoxon-rank scores with SAS (SAS Inc., Cary, NC), which compared the responses among different herd size groups. It was analyzed in this manner because it was suspected that greater opportunities for nutritional grouping would exist with larger herd size. For both WI and MI, these groups were defined to have a similar number of farms in each group. To assess the responses between WI and MI at similar herd sizes, MI surveys were divided in 2 herd-size categories: those farms with $<200$ lactating cows and those farms $\geq 200$ lactating cows. Therefore, herd size categories in WI were 200-250, 251-380, 381-525, 526-802, and >802 lactating cows. Herd size categories in MI for $\geq 200$ lactating cows were 200-240, 241-310, 311-420, 421-600, and $>600$. Herd size categories in MI for $<200$ lactating cows were $<40,40-62,63-89,90-132$, and $>132$. In addition, an ANOVA was conducted within the questions of physical grouping, feeding groups, and constraints to feeding groups of lactating cows to compare the significance among the options within each question and among these questions. Significance was declared at $P$ $\leq 0.05$.

\section{RESULTS AND DISCUSSION}

The survey return rate was 20\% in WI (196 questionnaires returned) and $26 \%$ in MI [211 questionnaires; $28 \%$ (59) with $\geq 200$ lactating cows]. In WI, farms in the range of 200 to 400 cows had the greatest frequency (91 farms), whereas in MI farms $<200$ lactating cows had the largest frequency (152 farms, Figure 1). Average herd size for WI was 603 lactating cows $(\mathrm{SD}=493$; Table 1), with an average RHA of $12,157 \mathrm{~kg} /$ cow per year $(\mathrm{SD}=1,409)$, ranging from 7,031 to $14,969 \mathrm{~kg} /$ cow per year, and average daily milk yield of $37.5 \mathrm{~kg} /$ cow per day $(\mathrm{SD}=4.7)$, ranging from 13.6 to $47.6 \mathrm{~kg} /$ cow per day. Average herd size for all respondent farms in MI was 205 lactating dairy cows $(\mathrm{SD}=320)$, with an average RHA of $10,393 \mathrm{~kg} /$ cow per year $(\mathrm{SD}=1,940)$, 
Table 1. Description of the herds and dairy farmers participating in the survey

\begin{tabular}{lcc}
\hline Item & $\begin{array}{c}\text { Wisconsin, } \\
\mathrm{n}=196\end{array}$ & $\begin{array}{c}\text { Michigan, } \\
\mathrm{n}=211\end{array}$ \\
\hline Number of cows & & 205 \\
Average & 603 & 106 \\
Median & 430 & 320 \\
SD & 493 & 10,393 \\
Rolling herd average (RHA; kg/cow per year) & 12,157 & 5,443 \\
Average & 7,031 & 15,876 \\
Minimum & 14,969 & 1,940 \\
Maximum & 1,409 & 31.8 \\
SD & & 10.6 \\
Milk yield (kg/cow per day) & 37.5 & 77.6 \\
Average & 13.6 & 7 \\
Minimum & 47.6 & 4.7 \\
Maximum & & 38.4 \\
SD & 37.8 & 14.7 \\
Nutrition management (\% of total respondents) & 32.1 & 35.0 \\
Feed company & 3.6 & 25.5 \\
Owner or farmer & & \\
Other & & \\
\hline
\end{tabular}

${ }^{1}$ Combination of 2 or more services, such as feed company, consultant, owner or farmer, and veterinarian.

ranging from 5,443 to $15,876 \mathrm{~kg} / \mathrm{cow}$ per year, and average daily milk yield of $31.8 \mathrm{~kg} / \mathrm{cow}$ per day $(\mathrm{SD}=$ 7), ranging from 10.6 to $47.6 \mathrm{~kg} / \mathrm{cow}$ per day (Table 1). Similar to WI, bigger farms had greater RHA and daily milk yield than smaller farms in MI. Farms with $\leq 200$ lactating cows had an RHA of $9,660 \mathrm{~kg} / \mathrm{cow}$ per year $(\mathrm{SD}=1268)$ and a daily milk yield of $30 \mathrm{~kg} / \mathrm{cow}$ per day ( $\mathrm{SD}=4.5)$, whereas farms $\geq 200$ lactating cows had an RHA of $11,761 \mathrm{~kg} /$ cow per year $(\mathrm{SD}=639)$ and a daily milk of $36.1 \mathrm{~kg} /$ cow per day $(\mathrm{SD}=2.2)$.

Feeding 2 or more different diets to lactating cows was predominant in both states. In WI, $69 \%$ of the farms (136) fed 2 or more diets, $26.0 \%$ of the farms (51) fed a single diet, and $5.0 \%$ (10) fed some concentrate

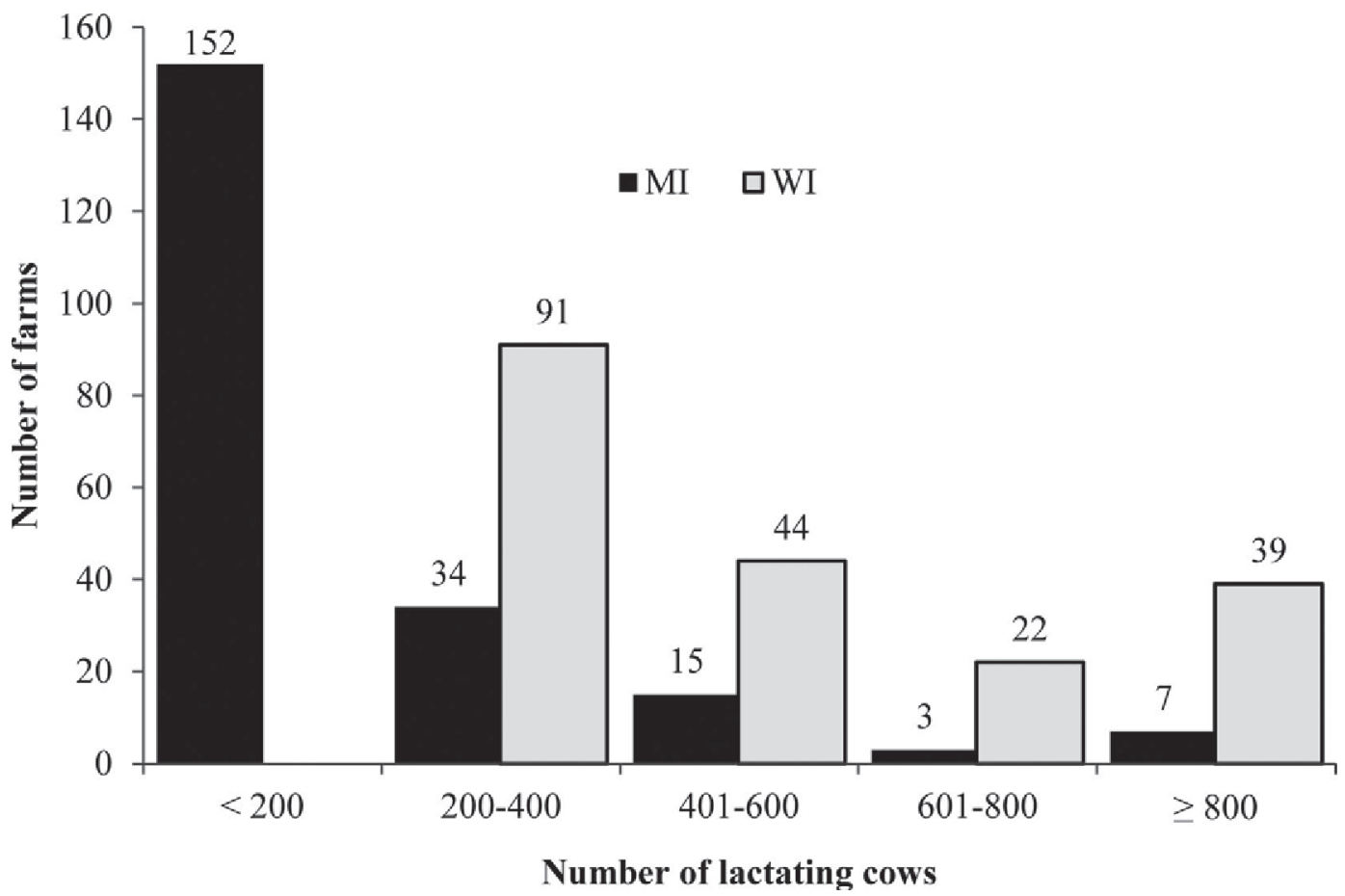

Figure 1. Distribution of herd size (lactating cows) of surveyed dairy farms in Wisconsin (WI) and Michigan (MI). 
on an individual basis to lactating cows. In MI, $64 \%$ of the farms with $\geq 200$ lactating cows (38) fed 2 or more diets, $22.0 \%$ (13) fed a single diet, and 14\% (8) fed some concentrate on an individual basis to lactating cows. In small MI farms ( $<200$ cows), $15 \%$ (23) fed 2 or more diets, $72 \%$ (109) fed a single diet, and $13 \%$ (20) fed some concentrate on an individual basis to lactating cows. A limitation of the current study is that the information collected with the questionnaire did not include the specifics of concentrates provided on an individual basis, which would have been important information to collect. These results indicate that a great number of dairy farms in both states are feeding 1 diet to all lactating cows. Allen (2009) indicated that grouping cows according to their nutrient requirements could increase profitability by improving milk yield and efficiency of milk production and reducing culling of over conditioned cows. Maltz et al. (2013) reported that feeding lactating cows according to energy requirements increased productivity by $3.2 \mathrm{~kg} / \mathrm{d}$.

\section{Criteria for Grouping Lactating Cows}

Similar trends were found in WI and MI for farms with $\geq 200$ lactating cows with respect to grouping of cows (regardless of using different diets; Table 2). In both WI and MI, farmers agreed or strongly agreed that having fresh cow groups and first lactation cow groups were the most important criteria for grouping (Table 2). The third-most-cited criteria were different between the states. In WI, health issues and the need to keep pens full of cows were the next-most-important grouping reasons, whereas in MI, DIM, health issues, and milk production level were next-most important; all criteria had similar rankings (rank from 3.6 to 3.9). The fourth-most-noted criteria were also different be- tween the 2 states. In WI, they were DIM, milk production, and reproduction ( $\mathrm{rank}=3.3$ ), whereas in $\mathrm{MI}$ it was need to keep pens full ( $\mathrm{rank}=3.5)$. Also, in both WI and MI significant differences in magnitude among farm sizes were noted when respondents indicated the need to have a fresh cow group (Figure 2). In WI, differences were significant for farms with a herd size of 200 to 250 lactating cows and those with $>251$ lactating cows (rank 4.2 vs. $\geq 4.6$ ); but overall all farmers agreed or strongly agreed that having a fresh cow group was important to have. In MI, farmers with farms with herd size of $\geq 311$ lactating cows strongly agreed that this criterion was important for grouping (rank >4.5), but for farmers with a herd size of $<311$ lactating cows it was less important (rank $\leq 4.2$ ). Similar differences also were found for the need to keep pens full in WI farms (data not shown). However, differences among farmers with different herd sizes was just in magnitude (rank 3.3 vs. 4.0), because farmers did not agree or disagree (neutral) with that statement.

In MI, farmers with herd size of $<200$ lactating cows responded similar in the criteria, but differently regarding the importance of grouping cows than those with herd size $\geq 200$ lactating cows (Table 2). For smaller farms the health issues were more important (rank = 3.3 ), as were the need to have a fresh cow group (rank $=3.3$ ), milk production level ( $\mathrm{rank}=3.3$ ), DIM (rank $=3.1$ ), and BCS ( rank = 3.1), but all responses were close to neutral (rank $=3.0$ ). Among all farms with $<200$ lactating cows, the only differences were in the "need to have a fresh cow group" and "I don't believe differentiating groups has any impact." Even though differences were observed among herd size for the first (Figure 2) and second criteria (data not shown), in both cases ranks were below 4.0 toward neutral and disagreement. Michigan farmers with herds $\geq 63$ lactating cows

Table 2. Reasons for physical grouping of lactating cows; level of agreement (strongly agree $=5$ ) or disagreement (strongly disagree $=1$ )

\begin{tabular}{lcccc}
\hline & Wisconsin & & \multicolumn{2}{c}{ Michigan } \\
\cline { 2 - 3 } Item & $\begin{array}{c}\text { Herd size } \geq 200 \\
(\mathrm{n}=196)\end{array}$ & $\begin{array}{c}\text { Herd size } \geq 200 \\
(\mathrm{n}=59)\end{array}$ & $\begin{array}{c}\text { Herd size }<200 \\
(\mathrm{n}=152)\end{array}$ \\
\hline Need to keep pens full of cows & $3.7^{\mathrm{c}}$ & & $3.5^{\mathrm{cd}}$ & $2.7^{\mathrm{c}}$ \\
Need to have a fresh cow group & $3.6^{\mathrm{a}}$ & & $4.5^{\mathrm{a}}$ & $3.3^{\mathrm{a}}$ \\
DIM (stage of lactation) & $4.3^{\mathrm{b}}$ & & $3.9^{\mathrm{b}}$ & $3.1^{\mathrm{ab}}$ \\
Need to have a first lactation heifer group & $3.2^{\mathrm{d}}$ & & $3.3^{\mathrm{a}}$ & $3.6^{\mathrm{b}}$ \\
Milk production level & $2.9^{\mathrm{e}}$ & & $3.0^{\mathrm{e}}$ & $3.3^{\mathrm{a}}$ \\
BCS & $3.8^{\mathrm{c}}$ & & $3.7^{\mathrm{bc}}$ & $3.3^{\mathrm{b}}$ \\
Health issues & $3.3^{\mathrm{d}}$ & & $3.3^{\mathrm{de}}$ & $3.0^{\mathrm{b}}$ \\
Reproduction & $1.8^{\mathrm{f}}$ & & $1.6^{\mathrm{f}}$ & $2.9^{\mathrm{b}}$ \\
I don't believe differentiating groups has any impact & 0.191 & & 0.310 & 0.233 \\
LSD $(P<0.05)$ & & & \\
a-f Means within column (effect of differences in reasons for grouping) with different superscripts differ $(P<$ \\
0.05).
\end{tabular}




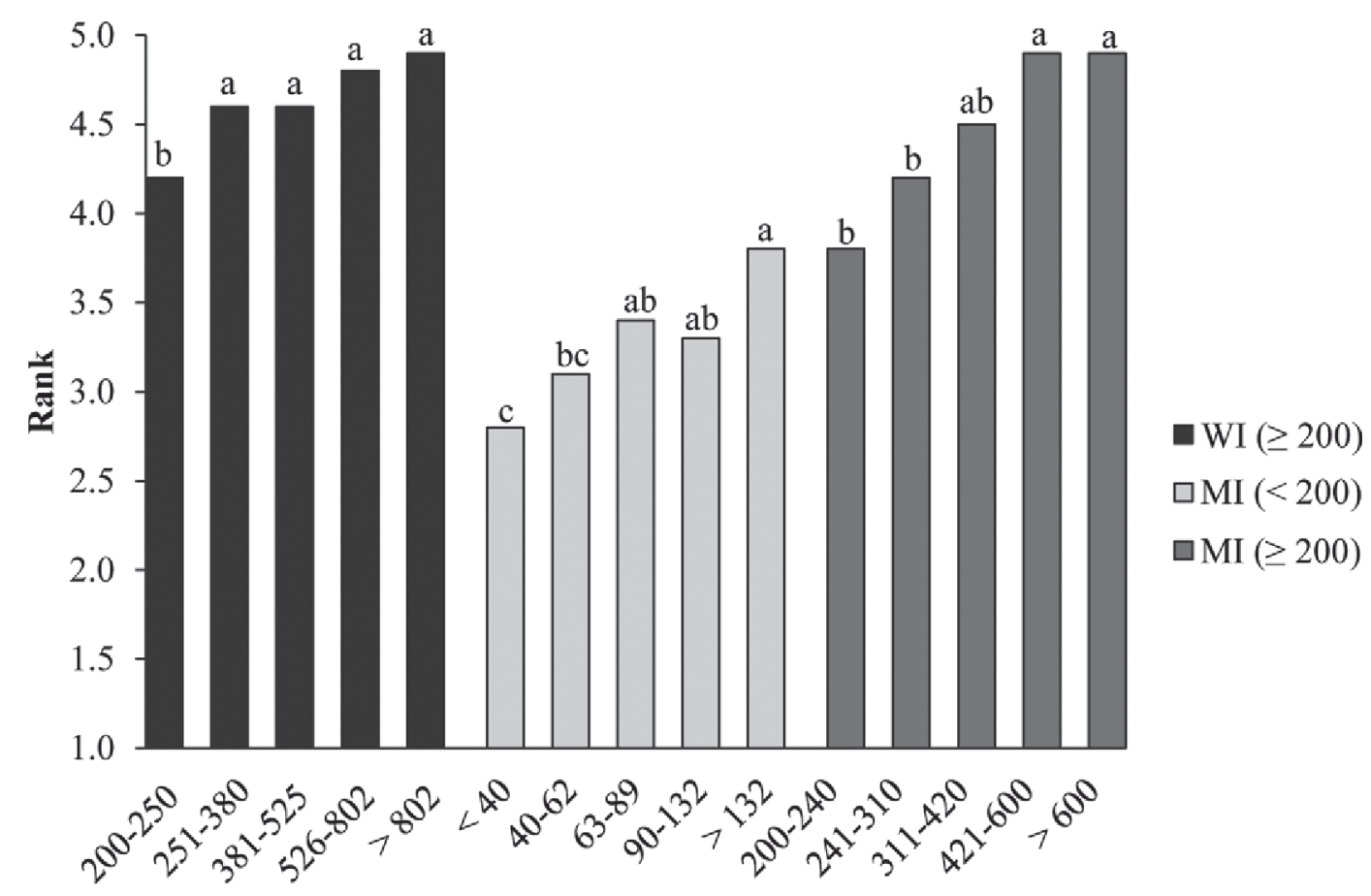

Herd size of lactating cows

Figure 2. Dairy producers' ranking of the need to have a fresh cow group based on herd size in Wisconsin (WI) and Michigan (MI). Columns within state and herd size with different letters $(\mathrm{a}-\mathrm{c})$ are different $(P<0.05)$.

slightly agreed (rank between 3.3 and 3.8) that having a fresh cow group was important, whereas farmers with herds < 89 lactating cows were between neutral (rank $=2.9)$ and toward agree $(\mathrm{rank}=3.5)$ that they did not believe differentiating groups had any impact.

In both states, the need to have a fresh cow group and the need to have a first lactation heifer group were the most important criteria for grouping lactating cows in farms with $\geq 200$ lactating cows ( rank $\geq 4.0$ ), whereas answers were of similar importance for the need to have a fresh cow group, milk production, and health issues in farms with $<200$ lactating cows in MI, but with a rank closer to neutral (rank $=3.3)$. Such a difference in the level of ranking between bigger and smaller farms could be an indication that, although dairy farmers with $\geq 200$ lactating cows are convinced that grouping is a good practice, farmers with fewer cows are not convinced that grouping is worth the effort. It is well documented that grouping based on nutrient requirements of dairy cows more homogeneous in protein and energy requirements can increase profitability by improving milk yield and efficiency (Williams and Oltenacu, 1992; St-Pierre and Thraen, 1999; Allen, 2009). Responses of farmers with herd sizes of $\geq 200$ lactating cows were also similar to those of previous reports (Grant and Albright, 2001). Using a fresh cow group from 1 or $3 \mathrm{wk}$ postpar- tum is commonly recommended to reduce competition among cows (Grant and Albright, 2001). In addition, a separate group of lactating primiparous cows can be of benefit because primiparous cows produce more milk when separated from mature cows (Phillips and Rind, 2001). Even though grouping cows based on nutrient requirements is a recommended practice for increased feed efficiency, it is not a routine practice for MI herd sizes $<200$ lactating cows.

\section{Criteria for Feeding Groups of Lactating Cows}

In both WI and MI, farmers agree and strongly agree that feeding a diet to fresh cows versus all other cows $(\mathrm{WI}$ rank $=4.5, \mathrm{MI}$ rank $=4.5)$ and feeding based on stage of lactation $(\mathrm{WI}$ rank $=3.4, \mathrm{MI}$ rank $=4.1$ ) were the most-important criteria for feeding groups of lactating cows (Table 3). Milk production was the third-most-important criteria in both states; parity and health issues were fourth and fifth in MI and health issues were fourth and parity and BCS tied for fifth in WI (Table 3). Among herd-size categories, a difference was noted in just 1 of the answers to question statements. In WI, differences were found among herd sizes for BCS (Figure 3). Farmers between 526 and 802 lactating cows considered BCS (rank $=3.2)$ as a basis 


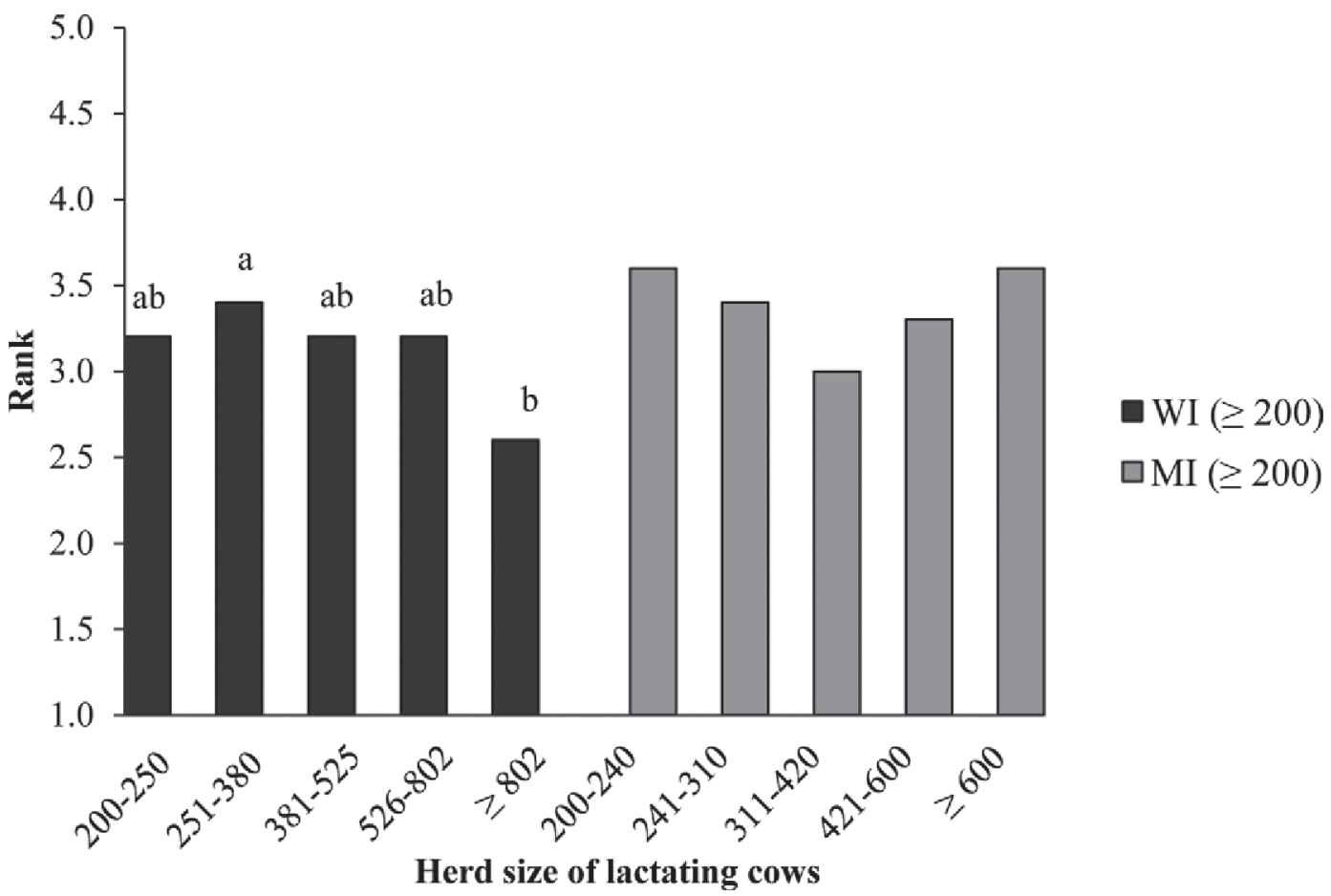

Figure 3. Dairy producers' ranking of BCS based on herd size in Wisconsin (WI) and Michigan (MI) for feeding purposes. Columns within state and herd size with different letters $(\mathrm{a}, \mathrm{b})$ are different $(P<0.05)$.

for feeding cows, which suggests they neither agree nor disagree, whereas farmers with $\geq 802$ lactating cows disagreed that feeding based on BCS was relevant (rank $=2.6$ ). There were differences among respondents by herd size in MI to the statement of "do not believe that more than one diet is needed" (data not shown). Farmers with herds of 421 to 600 lactating cows had very little agreement with that statement $(\mathrm{rank}=1.1)$, whereas farms with herds between 200 and 240 lactating cows gave a greater value $(\mathrm{rank}=2.2)$. In both cases, farmers disagreed with this statement that they do not believe more than 1 diet is needed, an indication that they likely agree that more than 1 diet is needed.

Farmers with $<200$ lactating cows in MI did not differ in their responses due to herd sizes. However, their responses were different from those of farmers with herd sizes of $\geq 200$ lactating cows. Milk production, stage of lactation, BCS, and the need to have a fresh cow group were the 4 main statements (ranks across groups were greater than 3.0; Table 3), but none of these farms

Table 3. Reasons for feeding groups of lactating cows; level of agreement (strongly agree $=5$ ) or disagreement (strongly disagree $=1$ )

\begin{tabular}{lcccc}
\hline & \multicolumn{2}{c}{ Wisconsin } & & \multicolumn{2}{c}{ Michigan } \\
\cline { 2 - 3 } \cline { 5 - 5 } Item & $\begin{array}{c}\text { Herd size } \geq 200 \\
(\mathrm{n}=196)\end{array}$ & & $\begin{array}{c}\text { Herd size } \geq 200 \\
(\mathrm{n}=59)\end{array}$ & $\begin{array}{c}\text { Herd size }<200 \\
(\mathrm{n}=152)\end{array}$ \\
\hline Fresh vs. all other lactating cows & $4.5^{\mathrm{a}}$ & & $4.5^{\mathrm{a}}$ & $3.4^{\mathrm{ab}}$ \\
Stage of lactation for nonfresh cows & $3.4^{\mathrm{b}}$ & & $4.1^{\mathrm{b}}$ & $3.5^{\mathrm{a}}$ \\
Parity (lactation number) & $3.1^{\text {ed }}$ & & $3.5^{\mathrm{c}}$ & $3.1^{\mathrm{b}}$ \\
Milk production level & $3.3^{\mathrm{bc}}$ & & $3.9^{\mathrm{b}}$ & $3.7^{\mathrm{a}}$ \\
BCS & $3.1^{\text {ed }}$ & & $3.1^{\mathrm{c}}$ & $3.5^{\mathrm{a}}$ \\
Health issues & $3.2^{\mathrm{cd}}$ & & $3.4^{\mathrm{c}}$ & $3.1^{\mathrm{b}}$ \\
Reproductive status & $2.9^{\text {ed }}$ & & $3.2^{\mathrm{c}}$ & $3.1^{\mathrm{b}}$ \\
I don't believe that more than one diet is needed & $1.8^{\mathrm{f}}$ & & $1.6^{\mathrm{d}}$ & $2.3^{\mathrm{c}}$ \\
I don't feed different diets due to constraints & $2.0^{\mathrm{f}}$ & & $1.8^{\mathrm{d}}$ & $2.6^{\mathrm{c}}$ \\
LSD $(P<0.05)$ & 0.212 & & 0.351 & 0.361 \\
\hline
\end{tabular}

$\overline{\mathrm{a}-\mathrm{f}}$ Means within column (effect of differences in reasons for grouping) with different superscripts differ $(P<$ $0.05)$. 
strongly agreed (rank $=5$ ) with those criteria for feeding (Table 3). Among herd sizes, milk production level was close to agree $($ rank $=3.9)$ for farms with herd sizes $<89$ lactating cows (data not shown). These responds indicated that, for farms with $<200$ lactating cows, there was not a specific criterion for feeding different diets other than level of milk production.

Feeding a different diet to fresh cows could be considered a standard nutritional management practice. Consequently, farms that would only differentiate lactating cows as fresh and nonfresh groups could be regarded as not exploiting additional nutritional grouping opportunities. Therefore, we counted all responses that either "agree" or "strongly agree" ( $\mathrm{rank}=4$ or 5 ) with the statement that they feed groups of lactating cows based on "fresh versus all other lactating cows" but did not "agree" or "strongly agree" with any other statement on feeding groups listed in Table 3; this resulted in $11 \%$ of farms in WI and $1.0 \%$ of farms in MI, which when added to previous results indicates that $37 \%$ of WI and $61 \%$ of MI farms fed only 1 additional diet to lactating cows besides the fresh cow group. More specifically, in MI, $34 \%$ of farms with $\geq 200$ lactating cows and $72 \%$ with $<200$ lactating cows fed only 1 diet to all lactating cows besides the fresh cow group.

\section{Constraints to Feeding more Diets to Lactating Cows}

In both WI and MI, "desire to keep it simple" (WI rank $=3.2, \mathrm{MI} \geq 200 \mathrm{rank}=3.0,<200 \mathrm{rank}=3.8)$ and "milk drops when cows are moved to a different group" (WI $=3.4, \mathrm{MI} \geq 200 \mathrm{rank}=3.2$ ) were the main limitations reported for not feeding more diets (Table 4). This latter constraint was not a surprise. One of the most common concerns among dairy producers is possible decreases in DMI and milk production when cows are moved from one nutritional group to another because of social adjustment or diet change (Albright, 1978; Grant and Albright, 2001; Allen, 2009). It has been well documented that dairy cattle are social animals that form dominance hierarchies when managed in groups, particularly at the feed bunk (Grant and Albright, 2001; von Keyserlingk et al., 2008). Social dominance correlates with age, body size, and seniority in the herd, and plays a role in a newly formed group (Grant and Albright, 2001). Group feeding of cows results in some degree of competition for feed. Typically, new cows in a group spend less time eating than before regrouping (von Keyserlingk et al., 2008). Traditionally, dairy cows have been managed in small groups (40-100 cows). However, as groups become larger, it is more difficult for cows to recognize group mates and their status in the social order of the group (Grant and Albright, 2001). This suggests that feed intake and milk produc- tion might not decrease as groups become larger. In a recent study, Zwald and Shaver (2012) compared daily milk yield per cow in 2 commercial dairy farms when providing the same diet to midlactation cows that were moved to a new group and cows that were not moved to a new group. Moving cows to a different group did not affect milk yield in either farm and no negative social effect of moving cows was observed between groups. In a different experiment, Talebi et al. (2014) evaluated the effects of changing stock density and pen size on the behavior in regrouping cows in late lactation (204 \pm 47 DIM) and indicated that regrouping and increasing stocking density can negatively affect cow behavior. They found that aggressive competition for resources increases after regrouping, which was worst during the first $3 \mathrm{~h}$ following fresh feed delivery when stocking density increased. Decreases in milk production due to social disturbances during regrouping have ranged from 2.5 (Albright, 1978) to 8.5\% (von Keyserlingk et al., 2008) compared with control animals, and lasted from 1 (von Keyserlingk et al., 2008) to $7 \mathrm{~d}$ (Grant and Albright, 2001).

Difference among herd sizes for one statement, "not enough personnel to handle it," in WI was only at the level of disagreement: disagree versus strongly disagree (data not shown). In WI, farmers did not agree that personnel were limiting more diets to lactating cows. For farmers with $<200$ lactating cows in MI, "farm facilities do not allow it" ( rank $=3.9$ ) was also a limitation for feeding more diets in addition to "desire to keep it simple." Therefore, in either farms with $<200$ or $\geq 200$ lactating cows, the "desire to keep it simple" was consistently more important. Demonstrating the benefits of grouping dairy cows via training workshops and management tools based on nutritional requirements, BCS, milk production, and stage of lactation likely increases adoption of nutritional grouping strategies.

\section{Housing Facilities, Nutrition Consulting, and Managers' Education}

In WI, $74 \%$ (145 farms) reported to be freestall, 3.0\% (5 farms) tiestall, and $23 \%$ (46 farms) did not specify. In MI, 55\% (115 farms) reported to be freestall, $18 \%$ (38 farms) tiestall, and 27\% (58 farms) did not specify. For farmers that reported freestall housing, $97 \%$ in WI and $80 \%$ in MI fed TMR; the other $3 \%$ and $20 \%$, respectively, fed a partial TMR with additional concentrate. In MI, farmers that reported tiestall housing (all these farms had $<200$ lactating cows) had more diverse feeding systems. Of these 38 farms, 8 fed a TMR and the other 30 fed using a combination of feeding systems which included partial TMR with additional concen- 
Table 4. Constraints to feeding groups of lactating cows; level of agreement (strongly agree $=5$ ) or disagreement (strongly disagree $=1$ )

\begin{tabular}{lcccc}
\hline & Wisconsin & & \multicolumn{2}{c}{ Michigan } \\
\cline { 2 - 3 } \cline { 5 - 6 } Item & $\begin{array}{c}\text { Herd size } \geq 200 \\
(\mathrm{n}=196)\end{array}$ & $\begin{array}{c}\text { Herd size } \geq 200 \\
(\mathrm{n}=59)\end{array}$ & $\begin{array}{c}\text { Herd size }<200 \\
(\mathrm{n}=152)\end{array}$ \\
\hline Current farm facilities do not allow it & $2.4^{\mathrm{c}}$ & & $2.5^{\mathrm{bc}}$ & $3.9^{\mathrm{a}}$ \\
Not enough labor or personnel to handle it & $2.2^{\mathrm{c}}$ & & $2.3^{\mathrm{cd}}$ & $3.3^{\mathrm{b}}$ \\
Desire to keep it simple & $3.2^{\mathrm{a}}$ & & $3.0^{\mathrm{a}}$ & $3.8^{\mathrm{a}}$ \\
Milk drops when cows are moved to different groups & $3.4^{\mathrm{a}}$ & & $3.2^{\mathrm{a}}$ & $3.1^{\mathrm{c}}$ \\
Conflicts with grouping for reproductive purposes & $2.8^{\mathrm{b}}$ & & $2.6^{\mathrm{bc}}$ & $2.9^{\mathrm{d}}$ \\
Nutritionist does not want to & $2.3^{\mathrm{c}}$ & & $2.1^{\mathrm{d}}$ & $2.5^{\mathrm{e}}$ \\
I don't believe more than 1 feeding group is needed & $2.3^{\mathrm{c}}$ & & $2.0^{\mathrm{d}}$ & $2.8^{\mathrm{d}}$ \\
LSD $(P<0.05)$ & 0.189 & & 0.298 & 0.218 \\
\hline
\end{tabular}

${ }^{\mathrm{a}-\mathrm{e}}$ Means within column (effect of differences in reasons for grouping) with different superscripts differ $(P<$ $0.05)$.

trate or forage, concentrate separate from forage, or top dress in the milking parlor.

In both states, nutrition management work for farms with $\geq 200$ lactating cows was done through feed companies (WI $=39.3 \%, \mathrm{MI}=18.6 \%)$, private consultants $(\mathrm{WI}=31.1 \%, \mathrm{MI}=47.5 \%)$, and a combination of 2 or more of these services $(\mathrm{WI}=25.5, \mathrm{MI}=32.2 \%)$. This task in farms with $<200$ lactating cows in MI was performed primarily by consultant services $(35.3 \%)$ and by the owner or family member $(19.3 \%)$, with less contribution by the feed company $(7.3 \%)$ and the combination of 2 or more services $(38.0 \%)$. Relatively few $(<3.6 \%$ in
WI and $<14.7 \%$ in MI) farmers did their own nutrition management work (Table 1). Consultants' services for nutritional management were indicated for 30 to $40 \%$ of all farms and herd sizes in both states. Consultants and feed company representatives are most often included in decision-making processes regarding the number of diets to be fed to lactating cows. It would be important to engage these services in any plan of training or technology transfer to dairy farmers. However, it should also be considered that, in farms with $\leq 200$ lactating cows, the owner of the farm and family members play a much more important role in the nutrition manage-

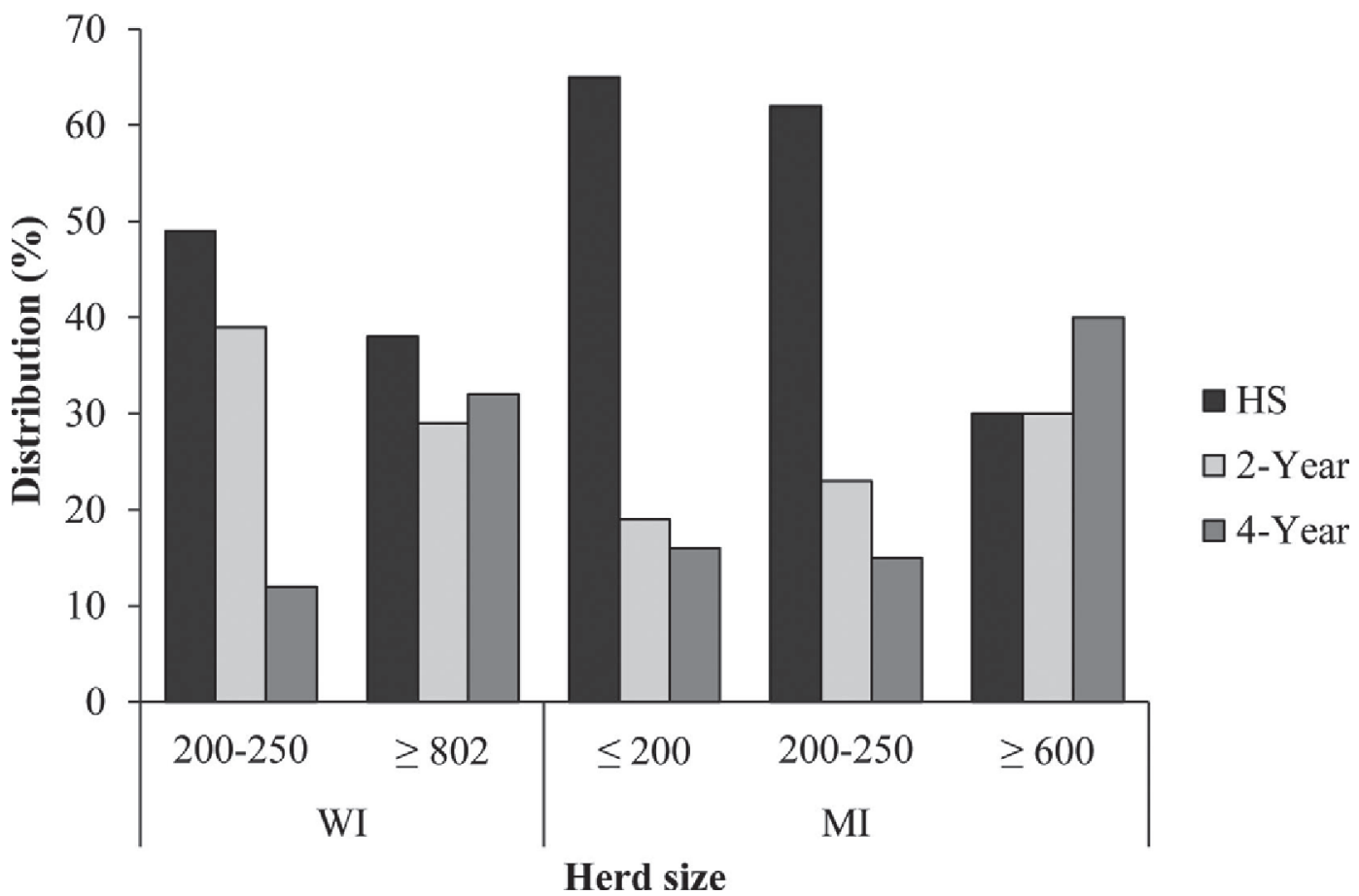

Figure 4. Level of education of the herd manager in Wisconsin (WI) and Michigan (MI) dairy farms: high school (HS), 2-year technical college (2-yr), and 4-year bachelor of science degree (4-yr). 
ment of the cows. The predominant level of education of the herd manager was high school diploma in both states (Figure 4). However, level of education differed depending upon herd size. As herd size increased, a trend toward the herd manager having higher formal education was observed.

\section{CONCLUSIONS}

About $34 \%$ of farms in WI and MI with $\geq 200$ cows fed just 1 diet to all lactating cows. This situation is more notable for those herds with $<200$ lactating cows in MI, where $72 \%$ fed just 1 diet. Farmers participating in this survey were not feeding more diets because they wanted to keep management simple and they had the perception that milk yield declines when cows are moved to a different group or given a different diet. However, from the total 407 completed questionnaires in both states, it was estimated that only $52.0 \%$ (211 farmers) practiced grouping for nutritional purposes and fed more than 1 diet in addition to a diet for fresh cows.

\section{ACKNOWLEDGMENTS}

Funding for this project was provided by Agriculture and Food Research Initiative Competitive Grant no. 2011-68004-30340 from the USDA National Institute of Food and Agriculture (Washington, DC). The authors are thankful to the Wisconsin Dairy Business Association (http://www.widba.com; Green Bay) for facilitating the mailing of questionnaires to Wisconsin farmers. The authors are thankful to the hundreds of Wisconsin and Michigan dairy producers that kindly provided the information required for this study. The authors also appreciate the comments and feedback of two anonymous reviewers that helped to improve the clarity of the paper.

\section{REFERENCES}

Albright, J. L. 1978. Social considerations in grouping cows. Pages 757-779 in Large Dairy Herd Management. C. J. Wilcox and H. H. Van Horn, ed. University Press of Florida, Gainesville.

Allen, M. S. 2009. Grouping to increase milk yield and decrease feed costs. Pages $61-65$ in Proc. Tri-State Dairy Nutr. Conf., Ft. Wayne, IN. The Ohio State University, Columbus.

Bowling, A. 2009. Research Methods in Health. Investigating Health and Health Services. 3rd ed. McGraw Hill. Open University Press, New York, NY.

Cabrera, V. E., F. Contreras, R. D. Shaver, and L. Armentano. 2012. Grouping strategies for feeding lactating dairy cattle. Pages 40-44 in Proc. Four-State Dairy Nutr. Manag. Conf., Dubuque, IA. University of Wisconsin Extension, Madison.

Grant, R. J., and J. L. Albright. 2001. Effect of animal grouping on feeding behavior and intake of dairy cattle. J. Dairy Sci. 84(E. Suppl.):E156-E163.

Maltz, E., L. F. Barbosa, P. Bueno, L. Scagion, K. Kaniyamattam, L. F. Greco, A. De Vries, and J. E. P. Santos. 2013. Effect of feeding according to energy balance on performance, nutrient excretion, and feeding behavior of early lactation dairy cows. J. Dairy Sci. 96:5249-5266.

McGilliard, M. L., J. M. Swisher, and R. E. James. 1983. Grouping lactating cows by nutritional requirements for feeding. J. Dairy Sci. 66:1084-1093.

Phillips, C. J. C., and M. I. Rind. 2001. The effects on production and behavior of mixing uniparous and multiparous cows. J. Dairy Sci. 84:2424-2429.

Schucker, B. L., M. L. McGilliard, R. E. James, and C. C. Stallings. 1988. A field study of grouping cows by nutrient requirements for feeding. J. Dairy Sci. 71:870-878.

St-Pierre, N. R., and C. S. Thraen. 1999. Animal grouping strategies, sources of variation, and economic factors affecting nutrient balance on dairy farms. J. Anim. Sci. 77(Suppl. 2):72-82.

Talebi, A., M. A. G. von Keyserlingk, E. Telezhenko, and D. M. Weary. 2014. Reduced stocking density mitigates the negative effects of regrouping in dairy cattle. J. Dairy Sci. 97:1358-1363.

VandeHaar, M. J., L. E. Armentano, and D. Moody Spurlock. 2012. Searching for a more efficient cow: Feeding and breeding to enhance efficiency. Pages 20-31 in 27th Ann. Southwest Nutr. Manag. Conf. Proc., Tempe, AZ. University of Arizona, Tempe.

von Keyserlingk, M. A. G., D. Olenick, and D. M. Weary. 2008. Acute behavioral effects of regrouping dairy cows. J. Dairy Sci. 91:10111016.

Williams, C. B., and P. A. Oltenacu. 1992. Evaluation of criteria used to group lactating cows using a dairy production model. J. Dairy Sci. $75: 155-160$.

Zwald, A., and R. D. Shaver. 2012. Case study: Effect of pen change on milk yield by dairy cows in 2 commercial herds. Prof. Anim. Sci. 28:569-572. 